\title{
Floristic Composition in Secondary Forests Located in a Tropical River Island - Brazil
}

\author{
Zviejkovski IP ${ }^{1 *}$, Leli IT ${ }^{2}$, Stevaux JC ${ }^{1,3}$ and Campos JB ${ }^{2}$ \\ ${ }^{1}$ State University of Maringá, Brazil \\ ${ }^{2}$ University of Western Paraná, Brazil \\ ${ }^{3}$ Universidade Estadual Paulista, Brazil
}

Submission: May 02, 2018; Published: August 23, 2018

"Corresponding author: : Zviejkovski IP, Post-graduation in Ecology of Continental Aquatic Environments, State University of Maringá, UEM, Av. Colombo, 5790, 87020-900, Maringá, PR, Brazil, Email: iupz@hotmail.com

\begin{abstract}
Fluvial islands are very changeable areas once they have vertical accretion by sediment from the flood as the same time as suffer erosion by channel flow. This factor acts directly over the characteristics of their vegetal cover in terms of composition and successional stages. In an island of the Upper Paraná River a floristic composition survey was performed in order to evaluate the plant succession stage of three forest fragments. The study areas were: Forest 1, an abandoned pasture under successional process over the last 10 years; Forest 2, a 55-year-old primary forest settled over a sand bar; and Forest 3, a fragment of a remaining forest. Floristic composition analysis showed that island soil has disturbed by trampling cattle reflecting on the species settlement throughout the successional process.
\end{abstract}

Keywords: Island vegetation; Secondary forest; Floristic survey; Abandoned pasture; Tropical river and Paraná River

\section{Introduction}

The Mata Atlântica biome is one of the most diverse of the planet and had in the last half of twenty century a dramatic reduction due to the processes of Brazilian colonization. The impact was so extreme that put this biome among the 34 hotspots of biodiversity leaving as inheritance the secondary forests that are composed predominantly of the Mata Atlântica [1]. Secondary forests are forests regenerating largely through natural processes after significant removal or disturbance of the original forest vegetation by human or natural causes [2]. When an agricultural or pasture area is abandoned its recovery can be slower or faster according to the interaction of biotic and abiotic factors [3]. Abandoned degraded areas tend to be naturally recolonized, resulting in major in a different landscape [4]. The secondary forest that grow in abandoned or not productive areas stand for a significant proportion of the total forest cover. The role of these forests in the structural and functional maintenance of biodiversity at the landscape level and its potential as a support for sustainable development depend on the intensification of studies on the dynamics of these forests and the current conditions in which they are found [5]. This problem is increased, when it comes to forest of fluvial islands. The changeable character of this islands, where accretion processes by flood sedimentation interact with erosional activity by water flow, may introduce a number of variables that are practically unknown in the literature [6]. This paper presents a contribution on the understanding of the insular vegetation dynamics in three forest fragments under different successional stages in an island of a large tropical river: the Upper Paraná, Brazil.

\section{Material and Methods}

The Porto Rico Island $\left(22^{\circ} 45^{\prime} \mathrm{S} / 53^{\circ} 15^{\prime} \mathrm{W}\right.$, at $230 \mathrm{~m}$ a.s.l.) is in the upper course of the Paraná River/Brazil. The river in the study reach is multi-channeled, with a mean annual discharge of $9.000 \mathrm{~m} 3 \mathrm{~s}-1$ and is included in the Ilhas e Várzeas do Alto Rio Paraná Environmental Protection Area. The regional vegetation belongs to the Semideciduous Seasonal Forest Phytoecological Region [7]. The Porto Rico Island was intensively deforested for pasture, lasting only 6.17 ha (8\%) of the original area of $93.3 \mathrm{ha}$ [8].The anthropic occupation was interrupted in 1997 with the creation of a "conservation unity", starting the processes of forest recovery and regeneration. This study analyzed three secondary forest fragments at different successional stages:

a) Forest 1: Abandoned pasture with a 10-year secondary forest

b) Forest 2: A 55-year primary forest developed over and ancients [9]

c) Forest 3: Remaining primary forest in the region, which has not been clear cut. Ten plots of $10 \times 10 \mathrm{~m}$ (0.1ha) were constructed for each forest fragment being identified the 
trees in with diameter at breast height greater than $15 \mathrm{~cm}$. The Importance Value Index - IVI [10] was calculated to each species.

\section{Results and Discussion}

Species composition was different for each fragment. In a total of 1431 specimens, it were found 44 species distributed into 26 families. The Forest 3 presented the largest number of species (31), followed by forest 2 (25) and Forest 1 (24) being 13 species common to the three fragments. The species presented different IVI for each fragment. Croton urucurana dominated the Forest 1 canopy, followed by Psidium guajava and the dead category, composed of dead trees. Cecropia pachystachya, Celtis iguanaea and Tabernaemontana catharinensis presented greater IVI in Forest 2. C. iguanaea was found only in forest 2 . The highest IVI in the Forest 3 was dead category, in its major composed by Cecropia pachystachya. Unonopsis lindmanii and Coussarea platyphylla get the second and third IVI in the Forest 3. Croton urucurana in Forest 1 occurred only in the flooded areas being a regional pioneer specie [11]. The impact by the ancient pasture in Forest 1 is reflected on the occurrence of the exotic invasive species Psidium guajava ("guava"). This specie also presents a high IVI in abandoned pasture areas elsewhere in tropical forests due to regrowth and dispersion. Its edible fruit is dispersed by birds and cattle [12-13]. Exotic species can hamper or impade the settlement of the pioneer and secondary species, modifying the local successional process. For the Forest 2 is in a very peculiar area of the island known as blind channel development and is very common in large multi-channeled tropical rivers [14]. An association of island and lateral bars generates a through-andcrest surface producing a complex surface where the troughs are normally swampy, with clayey organic soil, and the crests, are dry and with well-drained soil. This complexity of pedologic and hydric environments promote a diversification in vegetation. Although the Forest 2 presents higher IVI, Cecropia pachystachya was not present in the whole area, being restricted to the low frequently inundate places (troughs). According to Souza et al. 2005 , this specie is restrict to the areas near the channel, in places very wet due to its functional adaptations as the lenticels and adventitious root [15]. Celtis iguanea that was exclusive to this vegetal formation and had the second major IVI, presents characteristics of secondary species and occurs in natural levees with sand soil [9]. The Forest 3 presented higher IVI by dead category composed mainly by Cecropia pachystachya, a pioneer species, important in the local successional process. The death of individuals of this species, represents a natural succession process and the settlement of later groups as the climax species Unonopsis lindmanii and Coussarea platyphylla. In general, more advanced successional species became dominant when they find appropriated conditions as clearings produced by fall of trees [16].

\section{Conclusion}

The creation of the Ilhas e Várzeas do Alto Rio Paraná Environment Protection Area was fundamental to slow down the regional environmental degradation and vegetation recovery. However, the presence of $P$. guajava, exemplify the previous disorder promoted by cattle, what can lead to a change in the natural regional forest recovery pattern as presented in the Forest 3. For its time, Forest 2 presents the soil influence in species settlement during the successional processes. Unfortunately, the closure of the Porto Primavera Electrical Power Dam in 1999, 40 $\mathrm{km}$ upstream the reach, dramatic changed the river regime and sediment transport, the two main factors in fluvial morphology. At medium to long time (101 to 102 years) the process involved in island formation and maintenance can be totally modified and the island vegetal cover would be strongly affected [17].

\section{References}

1. Mittermeier RA, Robles Gil P, Hoffmann M, Pilgrim J, Brooks T, et al (2004) Hotspots revisited In: Earth's biologically richest and most endangered terrestrial ecoregions, CEMEX/Agrupación Sierra Madre, Mexico City, USA, pp. 392.

2. Food and Agriculture Organization of the United Nations (FAO) (2002) Tropical Secondary Forest Management in Africa In: realities and perspectives, Kenya, Africa.

3. Guariguata MR, Ostertag R (2001) Neotropical secondary forest succession: changes in structural and functional characteristics. For Ecol Manage 148(1-3): 185-206.

1. 4. Mesquita RCG, Ickes K, Ganade G, Williamson GB (2001) Alternative successional pathways in the amazon basin. J Ecol 89(4): 528-537.

4. Vieira ICG, Gardner TA (2012) Florestas secundárias tropicais: ecologia e importância em paisagens antrópicas. Bol Mus Para Emílio Goeldi Cienc Nat 7(3): 191-194.

5. Stevaux JC, Latrubesse EM (2017) Geomorfologia Fluvial. Oficina de Textos, São Paulo, Brazil, pp. 336,

6. Instituto Brasileiro de Geografia e Estatística (IBGE) (2012) Manuais Técnicos em Geociências: Manual técnico da vegetação brasileira, $\left(2^{\text {nd }}\right.$ edn.), IBGE, Rio de Janeiro, Brazil, pp.271.

7. Campos JB (1999) Spatial and multi-temporal analysis of deforestation and quantification of the remnant forests on Porto Rico Island, Paraná, Brazil. Braz Arch Biol Technol 42(1): 1190-1999.

8. Campos JB, Souza MC (2002) Arboreus vegetation of an alluvial riparian forest and their soil relations: Porto Rico Island, Paraná River, Brazil. Braz Arch Biol Technol 45(2): 137-149.

9. Müeller-Dombois, Ellenberg H (1974) Aims and methods of vegetation ecology. In: John Wiley, Sons, pp .547, New York, USA.

10. Campos JB, Souza MC (1997) Vegetação In: Vazzoler AEAM, Agostinho AA, Hahn NS (eds.), A planície de inundação do alto rio Paraná: aspectos físicos, biológicos e socioeconômicos. EDUEM/Nupélia, Maringá, Brazil, pp. 331-342.

11. Aide TM, Zimmerman JK, Pascarella JB, Rivera L, Marcano-Vega H (2000) Forest regeneration in a chronosequence of tropical abandoned pastures: implications for restoration ecology. Restoration Ecol 8(4): 328-338.

12. Pascarella JB, Aide TM, Serrano MI, Zimmerman JK (2000) Land-use history and forest regeneration in the Cayey Mountains, Puerto Rico. Ecosystems 3(3): 217-228.

13. Leli IT, Stevaux JC, Assine ML (2018) Genesis and sedimentary record of blind channel and islands of the anabranching river: An evolution model. Geomorphology 302: 35-45.

14. Campos JB, Romagnolo MB, Souza MC (2000) Structure, composition and spatial distribution of tree species in a remnant of the 
semideciduous seasonal Alluvial Forest of the upper Paraná River Floodplain. Braz Arch Biol Technol 43(2): 185-194.

15. Saldarriaga JG, West DC, Tharp ML, Uhl C (1988) Long-term chronosequence in the upper Rio Negro of Colombia and Venezuela. J Ecol 76(4): 938-958.
16. Stevaux JC, Corradini FA, Aquino S (2013) Connectivity processes and riparian vegetation o the Upper Paraná River, Brazil. J South Am Earth Sci 46: 113-121.

Your next submission with Juniper Publishers
will reach you the below assets
- Quality Editorial service
- Swift Peer Review
- Reprints availability
- E-prints Service
- Manuscript Podcast for convenient understanding
- Global attainment for your research
- Manuscript accessibility in different formats
( Pdf, E-pub, Full Text, Audio)
- Unceasing customer service
Track the below URL for one-step submission
https://juniperpublishers.com/online-submission.php

